\title{
MODEL DESA TERPADU PAUDNI MEWUJUDKAN MASYARAKAT PEMBELAJAR SEPANJANG HAYAT
}

\author{
Agus Sadid \\ e-mail: nenimarlina@gmail.com \\ Pamong Belajar SKB Kab. Sumbawa NTB
}

\begin{abstract}
Abstrak: Pola pembangunan desa harus menuju pada keterpaduan-integral dan berkelanjutan. Program PAUDNI berpotensi besar untuk menyejahterakan masyarakat desa. Untuk itu, desain model desa PAUDNI merupakan konsep yang ideal karena memberdayakan masyarakat desa secara terpadu. Masalahnya ialah bagaimana mengembangkan model desa terpadu PAUDNI untuk mewujudkan masyarakat belajar sepanjang hayat. Tulisan ini menelaah masalah tersebut dan mendeskripsikan desain model desa PAUDNI. Diharapkan dari desain ini, proses percepatan pemberdayaan dan peningkatan kesejahteraan masyarakat desa dapat terwujud dengan optimal. Hasil analisis menyimpulkan menunjukkan bahwa (1) desa PAUDNI dikonstruksi oleh teori Knowles dan Pannen, dengan menekankan pada sisi pemberdayaan masyarakat desa bersifat integral dan terpadu; (2) konstruksi desa PAUDNI meliputi partisipasi, kerjasama lintas sektoral, komitmen, dan integritas; (3) penerapan model desa PAUDNI harus mempertimbangkan data dan analisis potensi, pelibatan masyarakat dan keberadaan satuan PNFI seperti PKBM, PAUD, LKP dan majelis taklim yang hidup di desa; (4) desa PAUDNI dalam proses pembinaannya meliputi beberapa tim yang berasal dari internal dan eksternal. Dengan karakteristik demikian, desa PAUDNI membuka ruang besar pada lintas sektoral untuk mempercepat kemandirian, kesejahteraan, dan pembentukan masyarakat pembelajar sepanjang hayat.
\end{abstract}

Kata-kata Kunci: model, desa terpadu, PAUDNI, masyarakat pembelajar sepanjang hayat

\section{INTEGRATED VILLAGE MODEL OF PAUDNI TO CREATE LIFE-LONG LEARNING COMMUNITY}

\begin{abstract}
The pattern of rural development should move towards an integral-concept of development. Early childhood education program, (PAUDNI) has a huge potential to enhance people's welfare. The village model of PAUDNI would be the best alternative solution of empowering community. The problem is how to develop the integrated village model that establishes a life-long learning community. This article describes, discusses, and explores the integrated village model of PUDNI. The conclusion is (1) the PAUDNI village is constructed by the andragogy theory by Knowles and Pannen, emphasizing the community empowerment on integral and integrated aspects; (2) the construction of PAUDNI village model includes community participations, cooperation, commitment, and integrity; (3) the implementation of the model should consider data and analysis, community participation, PAUDNI Units such as PKBM, LKP, PAUD and other non-formal and informal groups; (4) in supervision and guidance process, the model of PAUNI village should involve some related people or institutions. Implementing such a village model properly would create a life-long learning community and enhance the social welfare and the life quality of the community.
\end{abstract}

Keywords: model, an integrated village PAUDNI, long-life learning community.

\section{PENDAHULUAN}

\section{Latar Belakang}

Desa sebagai sebuah organisasi pemerintahan pada level bawah, diakar rumput, memiliki peran yang strategis. Desa sejatinya merupakan pokok utama dari sesmua sasaran pembangunan mulai dari kabupaten/kota-provinsi dan pusat. Namun berbagai fakta di lapangan, pertumbuhan dan perkembangan desa masih belum optimal. Terdapat temuan di lapangan yang memperlihatkan, fungsi dan peran desa belum sejalan dengan visi misi pemerintah. Sehingga desa masih banyak yang "satgnan", lama berkembang dan cenderung terbelakang, padahal masyarakat hampir $70 \%$ masyarakat tinggal dipedesaan. Lambatnya perkembangan desa, tentunya berdampak kepada dinamika dan percepatan pembangunan, diantaranya kemiskinan, kebodohan, pengangguran dan terbatas 
akses infornasi.

Salah satu permasalahan yang kuat di desa adalah jumlah buta aksara yang sih besar. data Sebaran Buta Aksara Kemdikbud (2012) menyebutkan lebith dari $80 \%$ jumlah penyandang buta aksara ada di desa. Khusus untuk kondisi buta aksara ini secara nasional buta aksara tinggal 333.345 orang. Kondisi ini menuntut peningkatan kualitas layanan pendidikan keaksaraan, yang menurut Yuliawati (2012) meliputi 3 (tiga) layanan dasar yaitu kelompok usia yaitu (1) keaksaraan remaja 15-24 tahun, yaitu untuk mengukur pencapaian tujuan pembangunan Milineum atau MDG's, dan BPS telah mencatat keaksaraan pada kelompok usia ini telah mencapai 99,54\%, (2) keaksaraan dewasa usia 15-59 tahun yaitu untuk memenuhi target 2015 mencapai pendidikan untuk semua (education for all) dan (3) keaksaraan lanjut usia yaitu sebagai pemenuhan hak asasi warga negara atas pendidikan.

Fakta menunjukan bahwa sebuah negara dengan kualitas aksara yang baik, diikuti oleh kesejahteraan atau kualitas hidup yang lebih baik pula. Negara Korea, Jepang, China, dan Singapura, memiliki kebiasaan membaca rata-rata 4-5 jam sehari (Trisnamansyah, 2011). Kemampuan berkomunikasi, membangun pertemanan dan akses informasi terhadap pembangunan juga lebih baik. Bandingkan dengan negara kita, dimana kemiskinan dan buta aksara masih relatif lebih buruk dibandingkan dengan negara tersebut. Hal ini tentunya semakin menyulitkan upaya menigkatkan kualitas hidup mereka. Negara dengan kualitas aksara yang baik, mampu membentuk kondisi masyarakat pembelajar yang sangat kondusif, sehingga dampaknya masyarakatnya cerdas dan tidak mudah "dibodoh-bodohi". Berbanding terbalik dengan negara kita, agaknya tujuan mencapai masyarakat pembelajar, masyarakat dengan kualitas aksara yang baik, masih sulit tercapai, dengan kata lain masih jauh api dari panggang. Namun demikian, upaya harus terus digencarkan, sehingga disparitas buta aksara dan kemiskinan semakin kecil jaraknya.

Deskripsi di atas, tentang buta aksara, memberikan gambaran bahwa bagaimana "parahnya" kualitas SDM di desa. Buta aksara menyumbang nilai terbesar dalam indikator IPM (Indeks Pembangunan Manusia), karena itu pengentasan buta aksara harus berangkat dari desa dengan angka buta aksara yang tinggi. Jika kita tengok masalah lain misalnya terkait kemiskinan, pengangguran dan Angka Partisipasi (APK) PAUD, desa juga merupakan kawasan yang memiliki titik rawan. Data DitBinsusLat (2012) menunjukan bahwa angka kemiskinan nasional meningkat menjadi 28 , 28 juta pengangguran sebanyak 7,4 juta. Total jum- lah tersebut sekali lagi lebih dari $70 \%$ ada di desa. Demikian juga dengan APK PAUD secara nasional yang baru mencapai 58\% (Kemdikbud, 2012), artinya bahwa banyak anak usia 0-6 tahun yang belum terlayani oleh PAUD, padahal target Rencana Pembangunan Jangka Menengah (RPJM) Indonesia menargetkan capaian $75 \%$ sampai dengan tahun 2015 . Kondisi ini, semakin berat untuk terpenuhi, jika desa masih dijadikan sebagai objek pembangunan bukan subjek, pelaku dan pelibatan langsung dalam setiap proses pembangunan.

Membangun dan memberdayakan masyarakat desa harus dilakukan secara integral dan terpadu. Instrumen pendidikan melalui jalur Pendidikan Non Formal Informal (baca: PAUDNI), diyakini mampu memberikan tawaran solusi yang sangat rasional, dan argumentatif. Jalur PAUDNI selama ini sering terlupakan (baca: dilupakan) oleh pemerintah baik pusat-provinsi-dan daerah, sebagai alat untuk mensejahterakan masyarakat desa. Konsentrasi pembangunan masih sangat bercorak formal (formal-oriented). Kita bisa cermati, misalnya dari sisi kebijakan anggaran. Temuan penulis dilapangan menunjukan bahwa rata-rata hanya $5 \%$ anggaran pendidikan dari total $20 \%$ untuk PAUDNI, bahkan di beberapa kabupaten/ kota hanya mengalokasikan 0,5-2\% untuk PAUDNI. Temuan lainnya, banyak UPT SKB kab/kota "dibiarkan mati”, hidup segan mati tak mau, sehingga peran UPT SKB sebagai lembaga percontohan menjadi tidak optimal dan "mandul".

Kebijakan pembangunan pendidikan di Indonesia memang harus dibenahi, dibuat lebih berkeadilan dan humanis. Instrumen PAUDNI mampu memberikan penguatan dan perbaikan taraf hidup bagi masyarakat di desa-desa. Karakteristik PAUDNI yang lentur, kontekstual, tematik, berdasarkan kebutuhan masyarakat dan sangat dinamis dan beragam, (Sanapiah, 2003) merupakan alasan mengapa instrumen PAUDN mutlak diterapkan. Pembentukan desain desa Pendidikan Non Formal dan Informal (baca: PAUDNI) merupakan konsep pembangunan masyarakat desa yang berangkat dari-oleh-dan untuk masyarakat. Masyarakat sebagai basis kebutuhan merupakan inti dari desain model desa PAUDNI.

Beragam program PAUDNI seperti (1) pendidikan keaksaraan, (2) pendidikan kecakapan hidup, (3) pendidikan anak usia dini, (4) pendidikan pangurasataman gender, (5) pendidikan kesetaraan dan (6) pendidikan masyarakat, dapat menjadi "senjata" untuk memberdayakan masyarakat. Konsep desa PAUDNI adalah bagaimana menjadikan desa sebagai sentra pemberdayaan masyarakat melalui beragam program 
PAUDNI tersebut. Dalam desain desa PAUDNI sasaran utama adalah (1) para anak usia dini, (2) para ibu dan orang tua, (3) masyarakat miskin dan pengangguran, (4) kelompok pemuda produktif, (5) mayarakat tuna aksara, (6) perempuan miskin dan marginal. Kelompok sasaran tersebut harus tersentuh dengan program PAUDNI. Tujuan desain model desa PAUDNI adalah masyarakat sejahtera, berdaya, dan mayarakat pembelajar sepanjang hayat.

Berdasarkan paparan tersebut, maka tujuan dari tulisan ini adalah (1) mendeskripsikan bagaimana konsep desa terpadu -PAUDNI, (2) bagaimana model desain desa terpadu- PAUDNI serta (3) bagaimana strategi menerapkan desa terpadu-PAUDNI di masyarakat. Desa merupakan sentral pembangunan, dan desa pulalah yang harus mendesain dan merencanakan bentuk pembangunannya. Melibatkan masyarakat desa dalam kerangka pembangunan, akan semakin menjadikan desa mandiri. Konsep desain desa terpadu- PAUDNI merupakan gagasan untuk mempercepat keterwujudan masyarakat desa yang mandiri sehingga terbentuk masyarakat pembelajar sepanjang hayat. Manfaat yang muncul dari hasil kajian ini adalah (1) terdapatnya deskripsi tentang model desa terpadu- PAUDNI yang mampu menggerakan segala potensi desa menuju masyarakat pembelajar sepanjang hayat, (2) terdapatnya deskripsi langkah dan prosedur penerapan model desa terpadu-PAUDNI dalam suatu wilayah, paparan ini nantinya juga akan memberikan pemahaman tentang strategi pemberdayaan desa secara terpadu melalui sentuhan program PAUDNI.

\section{Kerangka Berpikir (frame of thinking)}

Memberdayakan desa bermakna memberdayakan orang-orang didalamnya, segenap potensi alam dan sumber daya manusianya. Desa selama ini banyak "dimanfaatkan", untuk keluar proyek tertentu, pada sisi ini desa hanya sebagai objek pembangunan. Padahal, masalah besar terkait dengan kemiskinan, pengangguran, penyakit sosial, keterbelakangan, buta aksara dan layanan PAUD semua bermula dari desa. Pola pembangunan harus berangkat dari-oleh-dan untuk masyarakat, pola penguatan masyarakat desa harus bersifat integral dan terpadu. Potensi program PAUD$\mathrm{NI}$, sebagai instrumen mensejahterakan masyarakat desa sangat besar, dan harus dilakukan cara terpadu. Desa harus disentuh dengan program PAUDNI yang beragam. Dalam satu desa maka, minimal program PAUDNI menyasar (1) anak usia dini, (2) ibu dan orang tua, (3) masyarakat miskin dan pengangguran, (4) perempuan miskin dan marginal, (5) buta aksara. Inilah yang menjadi konsep desain desa terpadu-PAUDNI, yang tentunya akan dapat mempercepat kesejahteraan masyarakat dan mencerdaskan sehingga akan terbentuk masyarakat pembelajar sepanjang hayat (Lifelong learning society).

\section{PEMBAHASAN}

\section{A. Masyarakat Pembelajar Sepanjang Hayat}

Masyarakat pembelajar merupakan sebuah kondisi yang muncul dari sistem pembelajar yang konstruktif. Masyarakat hakekatnya menghendaki sebuah perubahan, perubahan kearah yang lebih baik. Proses menuju perubahan tersebut dilakukan secara permanen, untuk menghasilkan perubahan yang berisifat permanen membutuhkan pendekatan yang partisipatif dan terpadu. Dinamika masyarakat juga memberikan sumbangan nyata terhadap proses perubahan yang diinginkan bersama. Siklus perubahan ditengah masyarakat membutuhkan perhatian yang serius. Bahwa dalam diri orang dewasa sebagai peserta didik yang sudah memiliki konsep dirinya yang mendalam yaitu keinginan dipandang sebagai manusia yang setara, memliki kelebihan dan kekurangan, memiliki pengalaman dan pengetahuan terhadap sesuatu hal. Untuk itu, pada proses pembelajaran dengan karakteristik warga belajar orang dewasa, tentunya harus memperhatikan kemampuan awal, bagaimana orang dewasa belajar sehingga tidak terkesan menggurui. Memberikan perlakukan yang sesuai dengan kebutuhan oranga dewasa akan mendorong tumbuhnya semangat masyarakat pembelajar.

Masyarakat pembelajar adalah setiap orang yang bersedia menerima tanggung jawab untuk melakukan dua hal penting yaitu (1) berusaha mengenal hakikat dirinya, potensi dan bakat-bakat terbaiknya dengan selalu mencari jawaban yang lebih baik tentang beberapa pertanyaan eksistensial seperti: siapa aku? Dari mana datangnya aku? Kemanakah aku akan pergi? Apa yang menjadi tanggung jawabku? dan (2) berusaha sekuat tenaga untuk mengaktualisasikan segenap potensi untuk mengekpresikan dan menyatakan dirinya sepenuh-penuhnya, seutuh-utuhnya dengan cara menjadi dirinya sendiri dan menolak untuk dibanding-bandingkan dengan sesuatu yang bukan dirinya, Harefa dalam (Julita, 2012).

Masyarakat pembelajar merupakan bagian yang tidak terpisahkan dari andragogi. Pendekatan andragogi yang efektif tentunya akan mendukung terwujudnya masyarakat pembelajar yaitu masyarakat yang 
dinamis, maju dan beradab. Sebagaimana dikuatkan oleh Edward (dalam Julita 2012) yang menekankan bahwa masyarakat pembelajar adalah masyarakat terdidik, pasar belajar dan peserta didik yang melakukan pendekatan belajar untuk hidupnya. Orang dewasa belajar untuk pengembangan dirinya, dia akan belajar jika dia merasakan bahwa apa yang dibutuhkan terpenuhi melalui belajarnya. Belajar karena memang dia meyakini bahwa apa yang dipelajari adalah kebutuhan dan berguna untuk kehidupanya. Mendorong terwujudnya masyarakat pembelajar melalui pendekatan andragogi memang tidaklah mudah. Membutuhkan komitmen dan kerja keras dari semua pihak, salah satunya adalah lingkungan belajar yang kondusif.

Membentuk suatu masyarakat pembelajar menurut Davies (dalam Julita, 2012) dapat dilakukan melalui langkah sebagai berikut (1) menciptakan komunitas pembelajar yaitu sebuah kelompok yang terbentuk berdasarkan minat tertentu bertujuan untuk pengembangan dri, misalnya komunitas baca utankayu, komunitas cinta kulinerr, (2) belajar dari pengalaman, bahwa belajar dari pengalaman dapat membekali peserta didik menjadi warga negara yang lebih baik, (3) memupuk pandangan dunia (world view) budaya baru, yaitu mengembangkan nilai-nilai dan keyakinan yang konsisten terhadap keberlangsungan hidup maka akan dibutuhkan pemahaman bersama tentang dunia yang indah dan bermakna dan (4) berpikir sistemik yaitu pemikiran yang menekankan pada pola, tren dan umpan balik. Pembelajaran dengan sistemik akan lebih fokus pada pemahaman terhadap interaksi antara manusia dan ekologi serta mengatur ulang sistem manusia untuk kelangsungan hidupnya.

Membangun sebuah komunitas masyarakat yang sarat dengan kegiatan pembelajaran harus dilakukan dalam kerangka pembelajaran sepanjang hayat. Pendidikan literasi, sebagai bagian dari komponen pendukung program pembangunan masyarakat pembelajar memberikan kontribusi dalam aspek bagaimana mengakrabkan warga masyarakat dengan kegiatan aksara. Aksara yang saling menguatkan, dan menbangun terbentuknya masyarakat pembelajar yang dicita-citakan. Komunitas-komunitas aksara haruslah dibangun disetiap desa. Komunitas ini berperan sebagai (1) wadah untuk para aksarawan baru untuk mengekspresikkan semua potensi dan kemampuan aksara yang telah dimiliki, (2) memberikan advokasi dan bimbingan kepada masyarakat di bidang keaksaraan, (3) mengembangkan aksara dalam konteks yang lebih luas dan menyentuh kepada kehidupan masyarakat. Konteks luas yang dimaksud adalah, bahwa aksara harus masuk kedalam nilai, budaya, ekonomi dan kesehatan. Bagaimanakah mengimplementasinya adalah melalui pembentukan komunitas cinta aksara, kirab aksara atau pawai aksara.

\section{B. Konsep PAUDNI}

Pendidikan Non Formal dan Informal (PNFI), sebagai salah satu jalur pendidikan sebagaimana disebutkan dalam UU nomor 20 tahun 2003 tentang Sistem Pendidikan Nasional, berperan sebagai penambah, pelengkap dan menguatkan satu sama lain dari semua jalur pendidikan. Perubahan istilah PNFI menjadi Pendidikan Anak Usia Dini, Non Formal dan Informal (PAUDNI) merupakan imbas dari perubahan nomenklatur oleh pusat. Istilah PNFI tentunya linier dengan makna PAUDNI. PAUDNI merupakan jalur pendidikan yang berakar pada kebutuhan masyarakat, basis PAUDNI adalah masyarakat akar rumput.

Karakteristik dari PAUDNI salah satunya adalah sasaran atau peserta didik, hampir $90 \%$ peserta didik PAUDNI adalah orang dewasa. Pada poin ini, maka pendidikan orang dewasa menjadi sangat relevan. Konsep pendidikan orang dewasa pertama kali dikenalkan oleh Knowles (1996) dan Pannen (1997). Konsep andragogi adalah pembelajaran menyangkut cara seseorang mempengaruhi individu atau makhluk bernyawa untuk belajar. Pembelajaran orang dewasa merupakan proses di mana orang dewasa belajar menjadi peduli dan mengevaluasi tentang pengalamannya. Berawal dari harapan penyelesaian terhadap masalah yang dihadapi untuk mengambil langkah-langkah sehingga terjadi perubahan perilaku yang baru yang tidak dimulai dari materi pelajaran. Peristiwa kehidupan menjadi pengalaman dan sumber belajar orang dewasa.

Knowles (1996) memberikan penjelasan lagi bahwa andragogi adalah pembelajaran digunakan untuk menunjukkan: (1) pemerolehan dan penguasaan tentang apa yang telah diketahui mengenai sesuatu; (2) penyuluhan dan penjelasan mengenai arti pengalaman seseorang; dan (3) suatu proses pengujian gagasan yang terorganisasi yang relevan dengan masalah. Smith, R. M. (1982) selanjutkan melengkapi bahwa pembelajaran digunakan untuk: (1) menjelaskan suatu hasil maka tekanannya diletakkan pada hasil pengalaman; (2) menyatakan suatu proses maka untuk menerangkan apa yang terjadi ketika suatu pengalaman pembelajaran berlangsung guna memenuhi kebutuhan mencapai tujuan; dan (3) menyatakan suatu fungsi maka difokuskan pada aspek-aspek tertentu seperti motivasi yang diyakini bisa membantu menghasilkan belajar.

Definisi pembelajaran orang dewasa menurut Morgan \& Barton, et al (1976) adalah suatu aktivitas 
pendidikan yang dilakukan oleh orang dewasa dalam kehidupan sehari-hari yang hanya menggunakan sebagian waktu dan tenaganya untuk mendapatkan tambahan intelektual. Menurut Reevers, Fansler, dan Houle dalam Suprijanto (2007) menyatakan bahwa, pembelajaran orang dewasa adalah upaya yang dilakukan oleh individu dalam rangka pengembangan diri, dimana dilakukan tanpa paksaan atau legal.

PAUDNI memiliki karakteristik yang menonjol yaitu (1) dilihat pada usia peserta didik, mengingat usianya sudah dewasa maka, para pendidik/tutor dan pengelola program PAUDNI harus memahami benar tentang konsep pendidikan orang dewasa (andragogi), (2) fleksibelitas, kelenturan yang ditawarkan dalam PAUDNI memang sangat khas. Program dan rancangan materi pembelajaran serta waktu belajar, disusun sepenuhnya oleh peserta didik. sehingga tidak memberatkan atau menganggu aktivitas pencarian kehidupan para peserta didik, belajar terlaksana, bekerja juga tetap dilakukan. (3) kontekstual, tema dan pilihan program belajar semuanya bersifat konstekstual, sesuai dengan kebutuhan belajar masyarakat. Orang dewasa hanya mau belajar jika apa yang dipelajari memberikan makna dan bermanfaat bagi mereka, maka apa yang dipelajari oleh peserta didik harus bermanfaat dan kontekstual serta relevan dengan permasalahan hidup peserta didik.

Program PAUDNI beragam dan dinamis itulah yang semestinya "dijual" kepada masyarakat luas, sehingga mampu menarik minat dan partisipasi masyarakat lebih besar. program PAUDNI yang dapat dikembangkan oleh masyarakat diantaranya adalah (1) program pendidikan keaksaraan, seperti keaksaraan fungsional, keaksaraan usaha mandiri dan keaksaraan inovasi, (2) program pendiidkan kesetaraan, seperti paket A setara SD, paket B setara SMP dan paket C setara SMA, (3) program pendidikan kecakapan hidup, seperti kursus, kewirausahaan masyarakat, (4) program pendidikan anak usia dini, seperti kelompok bermain, tempat penitipan anak, PAUD sejenis, (5) program pendidikan masyarakat, seperti desa vokasi, taman bacaan masyarakat, (6) program pendidikan penggurasatamaan gender, seperti koran ibu, pemberdayaan perempuan marginal, pelatihan keorangtuaan. Luasnya program, beragamnya program dan fleksibelnya waktu membuat program PAUDNI kaya dengan kreatifitas dan mampu menembus sekat-sekat kekurangan yang ada di masyarakat.

\section{Desa Terpadu PAUDNI}

Desa merupakan subjek pembangunan, untuk itu paradigma pembangunan harus mendorong sebanyak-banyaknya partisipasi masyarakat desa. Konsep inilah yang akan membentuk aksi pemberdayaan sebagaimana dikuatkan oleh Somodiningrat (1996) bahwa pemberdayaan dapat melibatkan dua kelompok yang saling terkait yaitu masyarakat yang belum berkembang sebagai pihak yang diberdayakan dan pihak yang menaruh kepedulian terhadap usaha pemberdayaan, dan proses tersebut bertahap, konsisten dan terus menerus. Partisipasi ini dapat masuk melalui tiga jurusan yaitu (1) menciptakan suasana dan iklim yang memungkinkan potensi masyarakat berkembang, (2) memperkuat potensi yang dimiliki masyarakat melalui pemberian berbagai input dan (3) mencegah pihak yang lemah semakin lemah.

Desain desa PAUDNI merupakan konsep memberdayakan masyarakat dengan target utama adalah mendorong partisipasi masyarakat agar peduli dan proaktif terhadaap program PAUDNI. Pada desain ini memang tujuan masyarakat mandiri merupakan hal yang utama. Melalui berbagai sentuhan PAUDNI dalam konteks pemberdayaan maka akan terbentuk siklus kemandirian masyarakat. Sebagaimana digambarkan oleh Honaddle\& Vant Sant dalam (Soetomo, 2006), sebagai berikut:

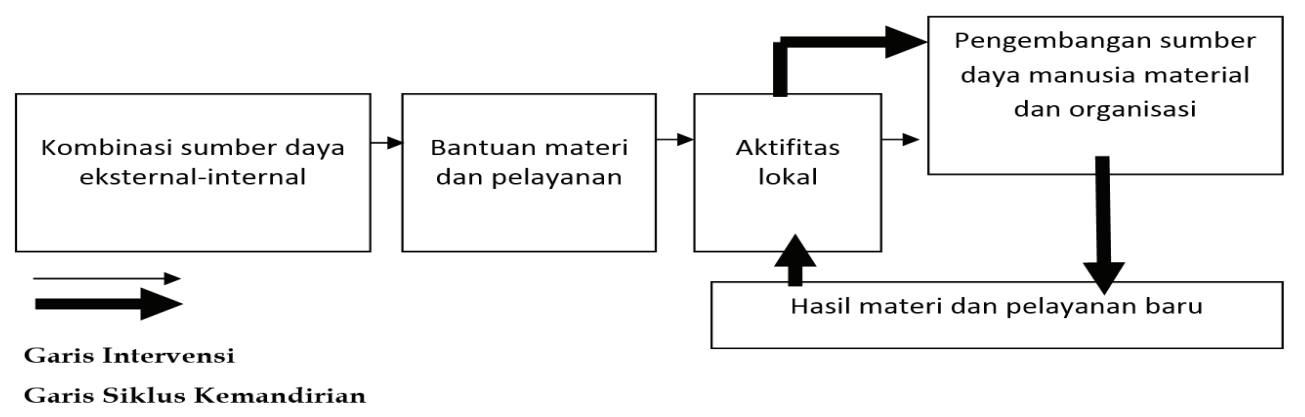

Gambar 1. Siklus kemandirian masyarakat (dari Homadle\&VantSant, 1984)

Jadi jika kerjasama stakeholders dapat menciptakan program yang diperuntukan bagi pemberdayaan masyarakat, maka kondisi yang menggambarkan masyarakat memiliki kemampuan untuk mengembangkan dirinya secara mandiri dan berkelanjutan dapat terwujud. Gondowardojo dan Prijosaksono dalam 
(Wiirosardjono, 1992) menyebutkan pendekatan tersebut dengan skema self propelling growth. Agar skema berhasil maka diutuhkan lima syarat yang meliputi (1) memiliki dimensi peran serta masyarakat yang nyata dan dalam pengertian yang luas, (2) mengandung potensi swadaya untuk menjamin keberlanjutan tanpa harus bergantung pada sumber daya dari luar secara terus menerus, (3) mencerminkan kegiatan bersama yang melibatkan pihak-pihak seperti pemerintah, swasta, LSM dan masyarakat lokal sendiri, (4) terbukti dapat menumbuhkan perkembangan yang berkelanjutan yang diukur dari keberhasilannya mengurangi kemiskinan dan kesenjangan sosial dan (5) memiliki sifat umum yang dapat dijadikan pola pengembangan swadaya, walaupun tetap tidak dapat dihindari adanya elemen yang bersifat khusus dan lokal.

Menilik pemikiran siklus kemandirian masyarakat di atas, maka tentunya konsep tersebut sejalan dengan desain desa PAUDNI yang dapat dikembangkan untuk meningkatkan kesejahteraan masyarakat, memandirikan sekaligus membentuk masyarakat pembelajar sepanjang hayat. Dalam gagasan sederhana penulis maka desain model desa PAUDNI terbagi dalam 2 (dua) konsep besar yang digambarkan dalam gambar 2.

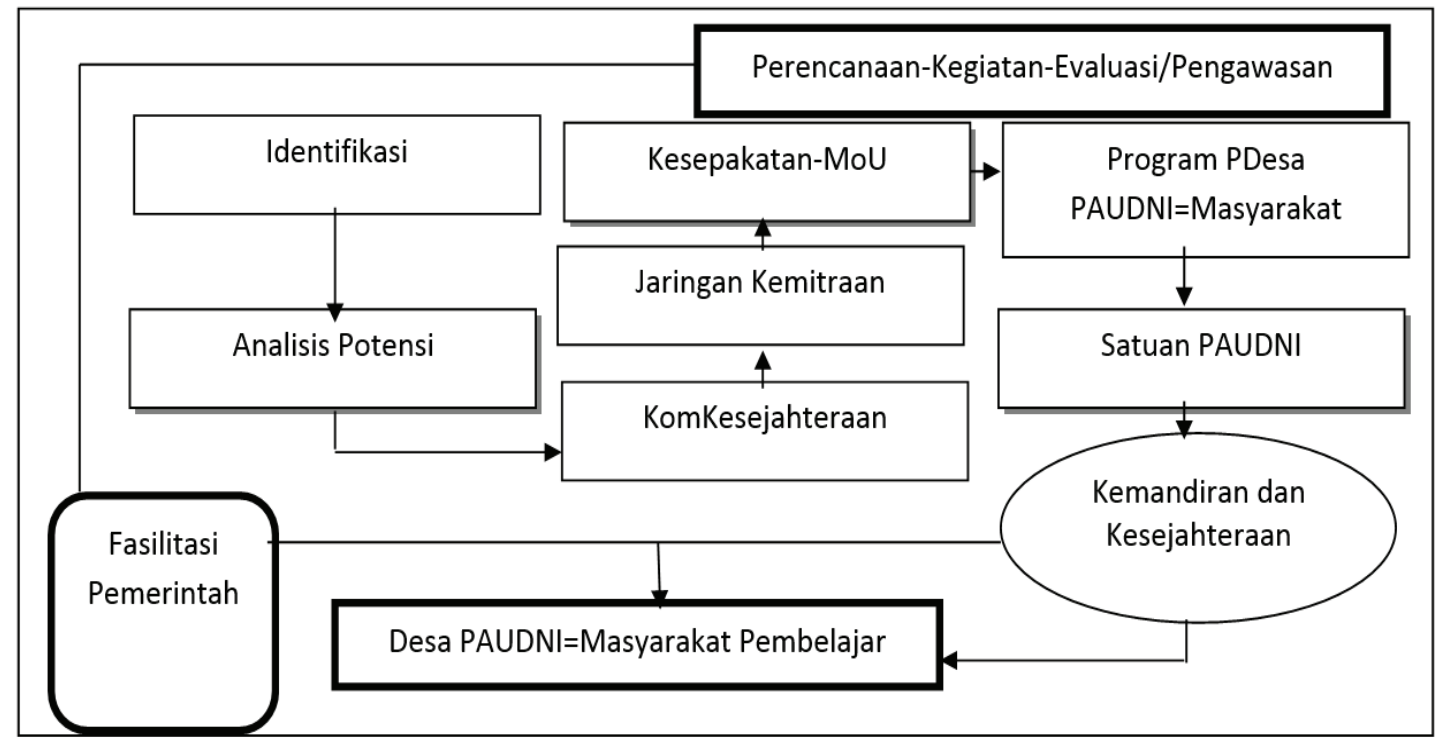

Gambar 2. Bangun konstruksi desa terpadu

PAUDNI

Konstruksi dasar desa terpadu PAUDNI adalah (1) ada analisis potensi dan kebutuhan belajar masyarakat, (2) ada pendekatan dalam pelaksanaan dilapangan seperti MoU,kemitraan dan komunikasi multi arah, (3) bentuk program PAUDNI yang menyentuh pada permasalahan kehidupan masyarakat, (4) ada satuan PAUDNI seperti TBM, PKBM, LKP, PAUD, kelompok belajar PNF dan majlis ta'lim. Peran pemrintah adalah faslitator, pemerintah pada jenjang daerah-propinsi dan pusat wajib memfasilitasi semua kebutuhan belajar masyarakat. Data dasar PAUDNI merupakan acuan dalam mengembangkan program sampai dengan implementasi di lapangan. Satuan PAUDNI merupakan ujung tombak pelaksanaan program PAUDNI di lapangan, untuk itu para pengelola satuan PAUDNI wajib memahami program PAUDNI dan memiliki integritas tinggi terhadap konsep pemberdayaan masyarakat. Mental-mental proyek yang selama ini ada dan hidup pada pengelola satuan PAUDNI harus segera dihilangkan. Pada konstruksi terakhir yaitu pengawasan adalah benteng terakhir untuk memberikan jaminan mutu, kepastian dan pengendalian. Peran penilik, UPT SKB kab/kota memainkan peran utama. Sedangkan dinasDikpora kabupaten/ kota memegang regulasi dan kebijakan terkait dengan keberlanjutan desa PAUDNI.

\section{Bentuk Model Desa Terpadu}

Desa PAUDNI sejatinya merupakan konsep yang sangat sederhana, yaitu (1) bagaimana memberdayakan masyarakat satu desa dengan menyasar para anak usia dini, ibu dan orang tua, penduduk miskin dan buta aksara, para pemuda produktif menganggur, dan perempuan miskin, (2) bagaimana kelompok sasaran tersebut selanjutnya diberikan sentuhan pemberdayaan melalui program PAUDNI dan (3) bagaimana program PAUDNI yang disentuhkan kepada mereka, benar-benar sesuai dengan kebutuhan belajar mereka. Model ideal desa terpadu paudni digambarkan dalam gambar 3. 


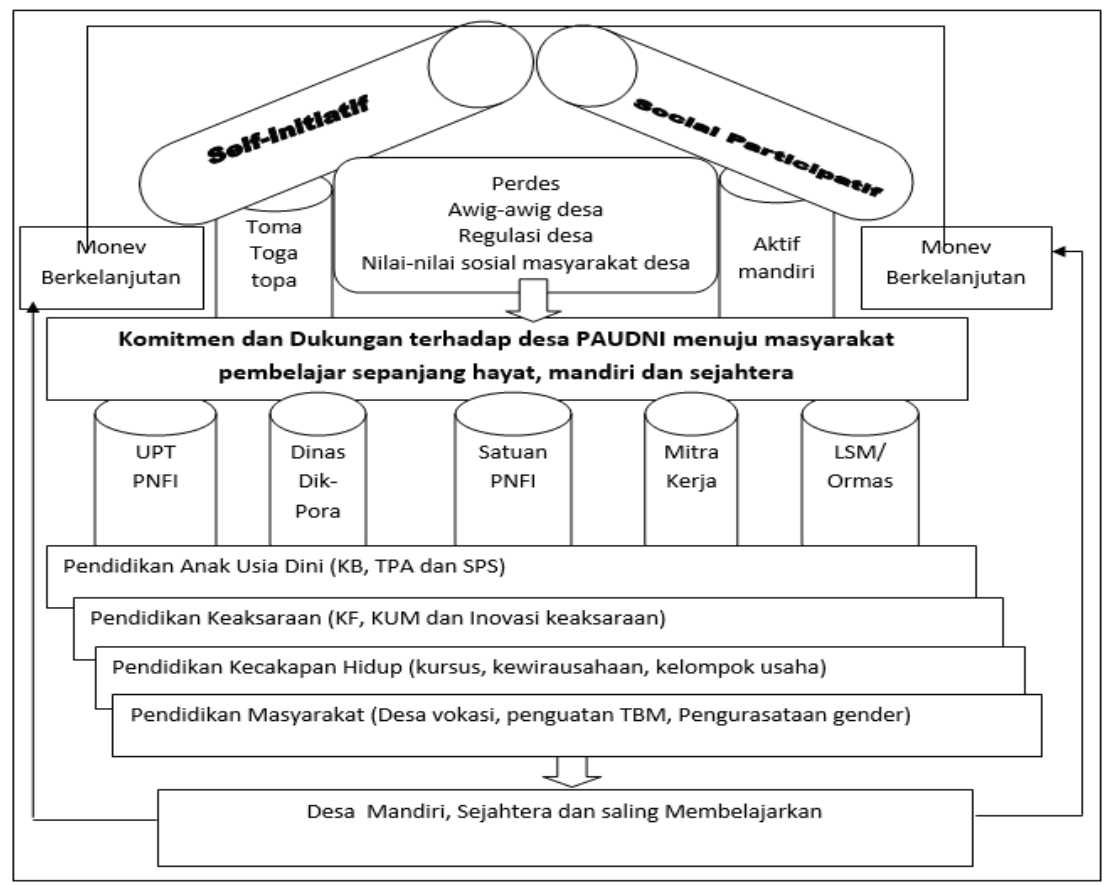

Gambar 3. Model ideal desa terpadu PAUDNI

Penjelasan terhadap desain model desa terpadu PAUDNI tersebut adalah sebagai berikut: Bahwa Model ini sebenarnya terbagi dalam 3 (tiga) episode, dimana episode pertama merupakan pra rencana dan perencanaan, episode kedua bentuk tindakan penguatan terhadap perencanaan tersebut dan episode terakhir adalah bentuk tindakan untuk mengisi sebuah model desa PAUDNI. Tindakan apa yang dilakukan pada episode pertama, yaitu sebagai berikut.

Pertama, desa terpadu PAUDNI harus berangkat dari keinginan masyarakat, melihat bagaimana kondisi keaksaraan yang terjadi didesa tersebut, sehingga memunculkan motivasi dan inisiatif warga masyarakat untuk merubah kampung/desanya menjadi lebih baik, dinamis dan sejahtera. Kedua, para Toma, toga dan topa, mencoba menginisiasi tentang rencana pembentukan kampung aksara, kemudian dilakukanlah sosialisasi secara intensif tentang apa yang dimaksud dengan visi dan misi desa PAUDNI tersebut, keterlibatan masyarakat menjadi kunci keberhasilan rencana tersebut

Ketiga, untuk memahamkan bagaiamana ide desa terpadu PAUDNI memang tidak mudah kepada masyarakat, sosialisasi dilakukan dalam periode waktu yang cukup lama 2-3 bulan. Keempat, setelah terbentuk pemahaman dan kesepakatan, bagaimana membangun desa yang lebih berkualitas melalui pembentukan, maka segeralah dibentuk peraturan atau regulasi yang menguatkan komitmen dan kesungguhan dalam membangun desa terpadu PAUDNI . Wujud dari kesungguhan tersebut dibuatkan Peraturan Desa atau Awig-Awig Desa, yang semua substansi regulasi tersebut mengarah kepada bagaimana mendorong penguatan pemberdayaan masyarakat melalui program PAUDNI, masyarakat cerdas dan gemar belajar untuk semua golongan. Pada pin ini juga harus selalu ditumbuhkan nilai-nilai yang menguatkan pada pembantukan masyarakat yang saling membelajarkan.

Pada episode kedua, setelah semua tahap awal terlampaui dengan baik, maka sebagai tindakan selanjutnya adalah intervensi penguatan yang dilakukan oleh pemerintah dan mitra kerja. Pada tahap ini, bentuk tindakan yang dilakukan adalah sebagai berikut:

Pertama, UPT PNFI baik di tingkat kabupaten/ kota, propinsi dan regional (baca: pusat) memberikan penguatan program untuk mendukung gagasan pembentukan desa terpadu PAUDNI . Program diberikan dalam bentuk bansos atau blockgrant PAUDNI kepada satuan PNFI seperti PKBM, PAUD, LKP, RBM, dan majlis taklim.

Kedua, dinas Dikpora baik ditingkat kabupaten/ kota dan propinsi menyiapkan program pemantauan, pembinaan dan pengendalian progrram desa terpadu PAUDNI tersebut. Fungsi instansi tersebut lebih bekerja pada area manajemen dan penyiapan regulasi yang menguatkan keberadaan desa PAUDNI. Regulasi tersebut sangat penting karena, akan memberikan dukungan kepada lintas sektoral agar mendukung program desa PAUDNI, mensinergikan dan mengkoordinasikan program-program sejenis yang berkaitan dengan pemberdayaan masyarakat.

Ketiga, satuan PNFI seperti PKBM, kelompok 
belajar keaksaraan, LKP dan PAUD memiliki peran yang besar dalam mendukung desain desa PAUDNI. Satuan PNFI tersebut merupakan ujung tombak dalam pelaksanaan program PNFI yang berada di desa PAUDNI tersebut. Dalam kampung aksara harus memiliki minimal 1 buah PBM, 1 buah LKP, 1 buah TBM, 1 kejar keaksaraan dan 1 buah lembaga PAUD.

Keempat, komponen LSM atau Ormas merupakan bentuk dukungan masyarakat internal terhadap keberadaan konsep desa PAUDNI. Kerjasama wajib dilakukan dalam bentuk kemitraan dengan LSM tersebut, karena LSM atau Ormas merupakan representasi dari keinginan masyarakat, sehingga sangat penting untuk mengajak mereka bersinergi dalam membangun desa PAUDNI. Kerjasama tersebut dalam bentuk apa saja, yang terpenting bertujuan untuk menguatkan konsep desa PAUDNI, seperti menjadi tutor, narasumber, satgas aksara, pembangunan pos baca, bahkan menjadi suplier penyedia bahan dan alat belajar serta buku-buku bacaan yang akan tersebar di pos baca atau TBM atau pondok baca.

Kelima, mencermati kelima pilar berbentuk tabung di atas, terdapat 3 buah pilar tabung yang lebih besar dari yang lainnya, itu menunjukan bahwa memang untuk menopang keberhasilan program desa PAUDNI pada episode kedua terletak pada (1) pilar UPT PNFI, (2) satuan PNFI dan (3) LSM atau ormas sebagai wujud keterlibatan masyarakat internal. Dengan kata lain, untuk masuk pada episode ketiga pembentukan sebuah desa PAUDNI, maka keberadaan ketiga lembaga tersebut harus diperkuat. Penguatan dilakukan pada sisi ketenagaan, sarana prasarana, dana, manajemen dan kelembagaan.

Masuk pada episode terakhir yaitu bentuk tindakan, aksi nyata dalam program desa PAUDNI adalah program yang terkait langsung dengan implementasi atau sentuhan program PAUDNI kepada masyarakat. Sentuhan prograam PAUDNI harus benar-benar menyasar pada kelompok sasaran yang telah ditetapkan yaitu (1) kelompok anak usia dini 0-6 tahun, (2) kelompok ibu-orang tua dan keluarga mskin, (3) kelompok buta aksara, perempuan marginal, (4) kelompok pemuda produktif menganggur atau tidak mampu dan (5) kelompok aksarawan baru yang ingin mengembangkan kualitas aksara. Bentuk sentuhan program PAUDNI harus terfokus pada kelompok rentan tersebut. Misalnya dalam satu keluarga ternyata keluarga tersebut masuk dalam kategori miskin, buta aksara, memiliki anak usia dini, maka keluarga tersebut wajib mendapat berbagai sentuhan program PAUDNI.

Jadi pada episode terakhir sebuah pembentu- kan desa PAUDNI, dilakukan melalui tindakan sebagai berikut:

1. Memperkuat struktur bangunan desa PAUDNI dengan intervensi program-program pro PAUDNI berbasis pada kebutuhan dan mendukung pro poor.

2. Membentuk kelompok-kelompok belajar PAUDNI yang dilakukan melalui rembug desa dan satuan PNFI

3. Memberikan stimulus program penguatan infrastruktur pendukung seperti berbentuk revitalisasi sarana prasarana pembelajaran untuk satuan PNFI seperti bantuan alat praktek, bantuan APE, bantuan bahan ajar, dan modul, bantuan rehabilitasi gedung PAUD, PKBM, TBM

4. Menguatkan kemampuan dan kemandirian masyarakat melalui program kelompok belajar usaha dengan jenis-jenis usaha yang memiliki peluang pasar dan atau sesuai dengan potensi sumber daya alam. Dari kelompok inilah maka akhirnya akan terbentuk sentra-sentra usaha khas kampung tersebut

5. Mendorong partisipasi masyarakat melalui proses pelibatan dari mulai perencanaan, pelaksanaan sampai dengan evaluasi atau pengawasan. Tentunya desain desa PAUDNI memang berangkat dari-oleh -dan untuk masyarakat, jadi masyarakatlah yang akan menjadi subjek sekaligus pengawas program desa PAUDNI tersebut.

4. Model Implementasi Desa PAUDNI

Mendaratkan atau mengimplementasikan model desain desa PAUDNI membutuhkan kesabaran dan ketekunan yang luar biasa. Ide desa PAUDNI berangkat dari kondisi bagaimana potret pembangunan desa masih belum mampu mengentaskan desa dari kemiskinan, keterbelakangan dan pendidikan. pola pembangunan desa masih cenderung bersifat partial, untuk itu perlu sebuah revolusi dalam pembangunan desa yaitu melalui model desa PAUDNI. Membangun desa PAUDNI membutuhkan juga kesabaran dan ketekunan dalam menciptakan atmosfir komunikasi dan pemahaman yang utuh terhadap desa PAUDNI dan ini tentunya memerlukan energi yang besar, karena ide ini belum tentu diterima oleh masyarakat desa tersebut.

Secara konseptual, implementasi model ini meliputi 4 (empat) komponen pokok sebagai pilarnya, yaitu (1) identifikasi, (2) analisis hasil identifikasi mencakup kualitatif dan kuantitatif, (3) perencanaan aksi yang matang dan (4) pembinaan secara berkelanjutan. Model implementasi Desa Paudi digambarkan dalam gambar 4. 


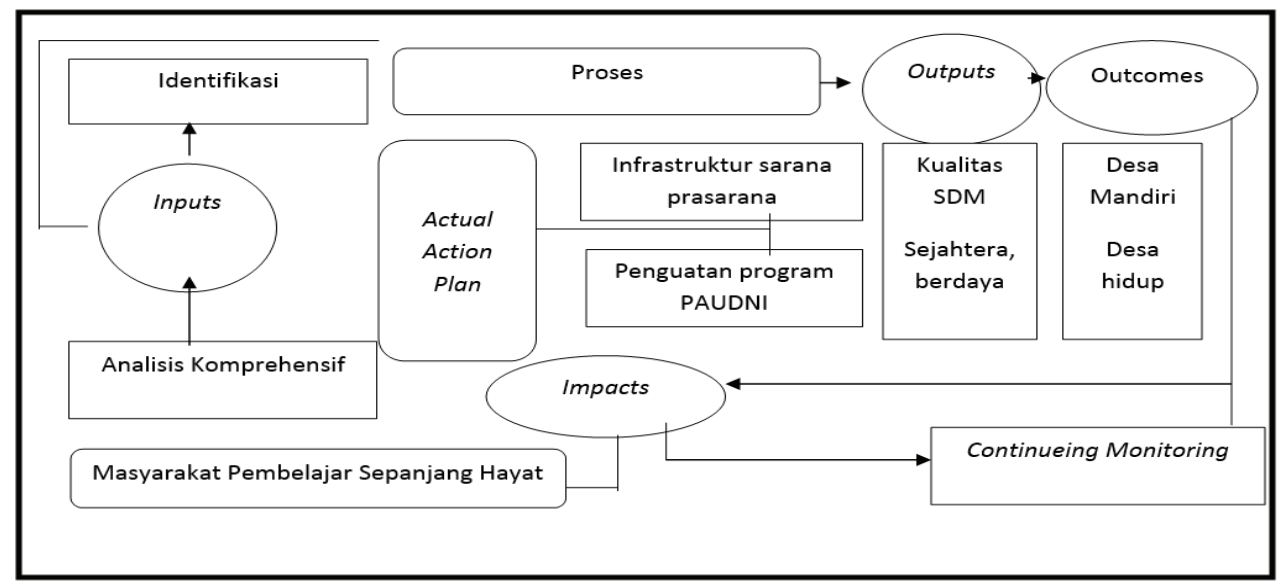

Gambar 4. Model implementasi desa terpadu PAUDNI

Merujuk pada chart di atas maka secara rinci dapat penulis deskripsikan sebagai berikut:

Pertama, melakukan persiapan pembentukan desa PAUDNI, harus melewati tahap awal yaitu identifikasi, atau prelimenary study (studi pendahuluan). Kegiatan ini merupakan tahap awal dilakukan, dimana bentuk kegiatannya adalah (1) mendata jumlah penduduk desa, (2) tingkat pendidikan, (3) jumlah anak usia dini, jumlah buta penyandang buta aksara dewasa usia produktif, (4) jumlah sarana atau fasilitas pendidikan, (5) tingkat pendapatan penduduk, (6) potensi sumber daya alam/ lingkungan desa dan (7) jumlah satuan PNFI yang ada di desa tersebut.

Kedua, hasil pendataan tersebut selanjutnya dilakukan analisis yang mendalam. Teknik analisis bisa menggunakan SWOT atau deskriptif. Hasil analisis ini nantinya harus dilakukan paparan dihadapan para praktisi dan akademisi, sehingga dapat pandangan atau penguatan terhadap hasil analisis tersebut. Kecerobohan dalam melakukan analisis, tentunya sangat buruk terhadap proses pembentukan desa PAUDNI. Pendapat dan pandangan para TOMA, TOGA sangat penting dijadikan sebagai data sekunder

Ketiga, selesai pada tahap pertama, maka melangkah pada tahap kedua yaitu proses. Dalam proses ini hal yang harus dilakukan adalah menyusun perencanaan operasional. Bagaimana membuat dan melengkapi infrastruktur sarana prasarana PAUDNI seperti APE, bahan ajar, buku bacaan, pos baca, pondok baca, dan sumber-informasi lainnya. Pada tahap ini harus dipertimbangkan bagaimana dinamika desa dan kelompok LSM,

Keempat, program PAUDNI sesuai dengan karakteristiknya, tentunya buka hanya didominasi oleh program dari Kemdikbud/Dikpora/Dinas Pendidikan, tetapi instansi lintas sektoral juga sangat diperbolehkan masuk memberikan intervensi pada program desa
PAUDNI, seperti Dinas koperasi dan UMKM, dinas Sosial, BPMPD, Depag, PKK, Dinas Pertanian, Dinas Perikanan dan Kelautan dan bahkan dinas Kesehatan

Kelima, tahap selanjutnya yaitu hasil, bahwa hasil yang akan nampak dalam program ini adalah kualitas SDM, meningkatnya pendidikan dan keterampilan. Jika kodisi ini telah terbentuk maka, akan menghasilkan keluaran lagi yaitu kesejahteraan masyarakat.

Keenam, pada tahap outcomes, yaitu mencapai desa mandiri, yaitu sebuah desa yang sarat dengan aktifitas belajar baik formal dan nonformal. Desa mandiri PAUDNI nantinya dicirikan dengan (1) meningkatnya derajat pendidikan dan kesejahteraan masyarakat, (2) dinamika desa yang baik, bergerak dan aktif, (3) tingginya kesadaran warga masyarakat terhadap pentingnya membaca, belajar dan saling membelajarkan sehingga akan terbentuk sebuah masyarakat yang berkualitas dan (4) berkembangnya satuan PNFI di desa, dengan beragam program PAUDNI yang dibutuhkan masyarakat dan berkualitas

Ketujuh, ialah dampak. Dampak yang harus muncul adalah terciptanya sebuah masyarakat pembelajar sepanjang hayat, yaitu sebuah masyarakat yang memiliki tingkat pengetahuan yang tinggi, dan mampu mengembangkan ketrampilan dan kemampuanya untuk mencapai derajat hidup yang berkualitas, dan membentuk sebuah masyarakat madani. Konsep inilah yang sejalan dengan pandangan Knowles (1976, 1980,1990 ) tentang masyarakat madani, masyarakat pembelajar sepanjang hayat, masyarakat yang mampu menolong dirinya dan lingkungannya dalam memecahkan permasalahan sehari-hari.

Kedelapan, pencapaian sebuah desa terpadu PAUDNI mulai darii rintisan sampai pada desa mandiri, harus dilakukan secara tekun dan berkelanjutan, dan tentunya semua proses dari tahap awal sampai akhir 
harus dilakukan pemantauan. Siapa yang memantau adalah dari (1) kalangan internal dan eksternal. Siapa kalangan internal? Yaitu dari unsur leading sectoral Dinas Dikpora kabupaten kota dan propinsi serta UPT PNFI. Sedangkan dari kalangan eksternal yaitu Bupati, Camat, Kades, BPD desa setempat dan LSM. Apa yang di monitoring? Yaitu pada aspek perencanaanpelaksanaan dan pasca kegiatan.

\section{E. Model Pembinaan Desa Terpadu PAUDNI}

Kegiatan pembinaan adalah bagian dari proses pengawasan untuk menjaga kualitas program (quality control). Pembinaan terhadap program desa terpadu PAUDNI dilakukan secara terpadu yaitu melibatkan unsur internal dan eksternal. Termasuk dalam tim internal adalah (1) dinas Dikpora kabupaten/kota dan propinsi, (2) UPT PNFI kabupaten/kota dan propinsi, dan (3) penilik PNFI di kecamatan masing-masing. Sedangkan tim eksternal yaitu tim dari luar, mereka tidak terlibat secara langsung, tapi merasakan dampak nyata dari program tersebut, sehingga secara moral memiliki tanggung jawab besar dalam mensukseskan program desa PAUDNI. Tim eksternal tersebut adalah (1) bupati/ walikota dan gubernur, (2) camat, (3) kepala desa setempat dan (4) LSM/NGO.

Mekanisme pembinaan adalah sebagai berikut; Pertama, pihak tim pembinaan internal melakukan rapat awal, membahas poin-poin yang akan diberikan pembinaan. Pembinaan terpadu tentunya melihat dari unsur perencanaan-pelaksanaan dan evaluasi kegiatan. Selanjutnya tim akan menyusun instrumen pembinaan. Poin-poin yang akan dilakukan pembinaan dan termuat dalam instrumen adalah (1) aspek pra perencanaan-perencanaan, (2) aspek penguatan program PAUDNI dalam bentuk program aksi PAUDNI misalnya pendidikan keaksaraan atau pendidikan anak usia dini (3) aspek pembentukan kelompok-kelompok belajar, (4) aspek proses pembelajaran dalam kelompok-kelompok belajar, (5) aspek pengembangan sarana prasarana, (6) aspek dukungan ketenagaan PTK dan (7) aspek tindak lanjut program.

Kedua, tim menyusun jadwal pembinaan secara periodik. Tim yang datang ke desa PAUDNI harus melaksanakan pembinaan terpadu dengan mengacu kepada ketujuh aspek pembinaan di atas. Tim mengunjungi desa PADNI minimal sebulan sekali. Ketiga adalah menindak lanjuti hasil temuan atau pembinaan. Laporan hasil pembinaan tidak boleh hanya sebagai dokumen tidak bermakna, tetapi setiap temuan yang uncul dari kegiatan pembinaan harus segera dilakukan solusi atau tindak lanjut dan Keempat adalah menyusun langkah konkret terkait dengan penanganan hambatan datau kendala dari kegiatan pembinaan.

Bahwa semangat dari kegiatan pembinaan adalah untuk memberikan peningkatan pelayanan dan kualitas program desa PAUDNI. Kegiatan pembinaan benar-benar difokuskan kepada hal-hal yang substantif yaitu bagaimana meningkatkan perjalanan program desa PAUDNI sebagai model inovatif. Berikut adalah chart model pembinaan desa terpadu PAUDNI yang digambarkan dalpada gambar 5 .

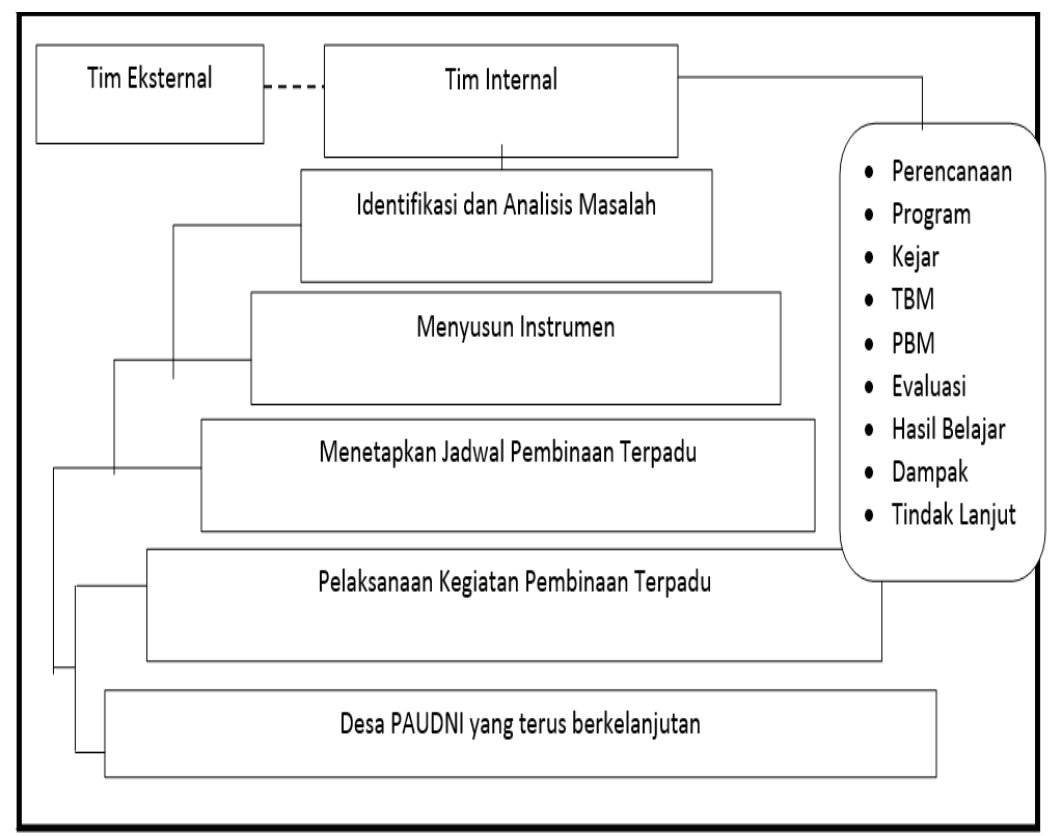

Gambar 5. Model pembinaan desa terpadu PAUDNI 


\section{PENUTUP}

\section{Kesimpulan}

Pertama, Desa Terpadu PAUDNI merupakan gagasan yang bertolak dari pemikiran bahwa (a) pola pemberdayaan masyarakat desa harus bersifat terpadu dan integral, saatnya meninggalkan pola partial dalam pembangunan desa, (b) kualitas SDM masyarakat desa sangat potensial dikembangkan melalui sentuhan program PAUDNI, karena program PAUDNI berangkat dari-oleh- dan untuk masyarakat, dan (c) karakteristik program PAUDNI yang fleksibel, kontekstual dan beragam sangat sesuai dengan masyarakat desa. Model pemberdayaan masyarakat harus mempertimbangkan prinsip-prinsip kebutuhan, partisipasi dan menempatkan masyarakat sebagai subjek pembangunan.

Kedua, konstruksi dasar Desa Terpadu PAUDNI adalah (a) ada analisis potensi dan kebutuhan belajar masyarakat, (b) ada pendekatan dalam pelaksanaan di lapangan seperti MoU, kemitraan dan komunikasi multi arah, (c) bentuk program PAUDNI yang menyentuh pada permasalahan kehidupan masyarakat, (d) ada satuan PAUDNI seperti TBM, PKBM, LKP, PAUD, kelompok belajar PNF dan majlis ta'lim. pada sisi desainnya, desa terpadu PAUDNI memberikan penekanan pada keterlibatan masyarakat, pengembangan jaringan, penerbitan perdes terkait dengan desa PAUDNI serta komitmen dan integritas pemerintah baik pusatprovinsi-daerah bahkan sampai ditingkat kecamatan dan desa menjadi desain utama dalam desa terpadu PAUDNI.

Ketiga, menerapkan desa terpadu PAUDNI memang bukan pekerjaan mudah tetapi keseriusan dan ketekunan semua pihak merupakan modal awal dalam nenerapkan konsep desa terpadu PAUDNI dilapangan. Secara konseptual, implementasi model ini meliputi 4 (empat) komponen pokok sebagai pilarnya, yaitu (a) identifikasi, (b) analisis hasil identifikasi mencakup kualitatif dan kuantitatif, (c) perencanaan aksi yang matang dan (d) pembinaan secara berkelanjutan. Dalam menerapkan model desa PAUDNI, kata kuncinnya adalah komitmen dan integritas. Keberpihakan dan kepedulian terhadap masyarakat desa, bagaimana mengeluarkan masyarakat desa dari berbagai ketertinggalan, harus terus dipegang dan desa PAUDNI akan dapat mempercepat tercapainya masyarakat yang mandiri, dan menuju masyarakat pembelajar sepanjang hayat.

\section{Saran}

Pertama, Bupati/ Walikota perlu menerapkan (a) konsep desa terpadu PAUDNI di kabupaten/kota, merekomendasikan program 1000 desa PAUDNI sebagai pilot projek pembangunan desa yang terpadu dan (b) perlu juga membuat penguatan yang lebih nyata terhadap implementasi desa terpadu PAUDNI

Kedua, Kepala Dinas Pendidikan/Dikpora kabupaten/kota (a) membuat regulasi yang dapat memberikan rasa nyaman, dan mendukung kinerja desa terpadu PAUDNI seperti membuat keputusan bersama antara SKB-BPKB-Dinas Dikpora dalam memberikan kegiatan tindak lanjut dan (b) membuat kesepakatan MoU antara lintas sektoral, terkait dengan programprogram pembangunan di bidang SDM di desa, dan menjadikan desaterpadu PAUDNI sebagai wadah yang efektif.

Ketiga, Kepala BPKB/SKB dan BPPAUDNI (a) membentuk sistem tata kerja dalam pembinaanmonitoring dan bimbingan teknis pada satuan PNFI pendukung desa terpadu PAUDNI dan (b) membuat program peningkatan kapasitas pengelolaan desa terpadu PAUDNI berbentuk pelatihan dan magang.

\section{DAFTAR PUSTAKA}

Julita. (2012). Pembentukan masyarakat pembelajar. Warta Plus Edisi XII Vol. 56 Tahun 2012. Jakarta: Dirjend PAUDNI Kemdikbud RI

Knowles, M.S. (1970). The modern practices of adult education: Andragogy versus. New York: Association Press

Knowles. M. (1980). The modern practice of adult education: From pedagogy to andragogy (2nd eds). Englewood Cliffs: Prentice Hall Combridge

Knowles, M.S, Holton, E.F. \& Swanson, R.A. (1998) The adult learner: The definitive classic in adult education and human resources development.
Houston, TX: Gulf Publishing

Morgan, Barton, et al. (1976). Methods in adult education. Danville, Illinois: The Interstate Printers \& Publishers, Inc.

Pannen, P Melati S Ida. (2003). Pendidikan orang dewasa. Program Applied Aprroach Jakarta: Universitas Terbuka

Soetomo (2006). Strategi-strategi pembangunan masyarakat. Yogyakarta: Pustaka Pelajar

Somodiningrat, G. (1997). Pembangunan daerah dan pemberdayaan masyarakat. Jakarta: Bina Rena Pariwara 
Smith, Robert M. (1982). Learning how to learn: Applied theory for adults. New York: Cambridge The Adult Education Education Company.

Trisnamansyah. (2011). Pengembangan model pembelajaran berbasis masalah untuk meningkatkan motivasi berprestasi warga belajar program PKH. Jurnal Visi P2TK PAUDNI Vol 6 No.1 Ta- hun 2011. Jakarta: Dit P2TKPAUDNI.

Yuliawati, E. (2012). Sambutan disampaikan dalam rangka Hari Aksara Internasional di Palangkaraya alteng, 29 September 2012

Wirosardjono, S. (1992). Pengembangan swadaya nasional. Jakarta: LP3ES 